\title{
Development of an In Vivo Method to Estimate Effective Drug Doses and Quantify Fatty Acid Amide Hydrolase in Rodent Brain using Positron Emission Tomography Tracer $\left[{ }^{11} \mathrm{C}\right] \mathrm{DFMC} \mathrm{s}$
}

\author{
Tomoteru Yamasaki, Tomoyuki Ohya, Wakana Mori, Yiding Zhang, Hidekatsu Wakizaka, \\ Nobuki Nengaki, Masayuki Fujinaga, Tatsuya Kikuchi, and Ming-Rong Zhang \\ Department of Advanced Nuclear Medicine Sciences, National Institute of Radiological Sciences, Quantum Medical Science \\ Directorate, National Institutes for Quantum and Radiological Science and Technology, Chiba, Japan (T.Y., T.O., W.M., Y.Z., \\ H.W., N.N., M.F., T.K., M.-R.Z.) and SHI Accelerator Service Co. Ltd, Tokyo, Japan (N.N.)
}

Received November 6, 2019; accepted March 27, 2020

\section{ABSTRACT}

Fatty acid amide hydrolase (FAAH) is a key enzyme in the endocannabinoid system. $N$-(3,4-Dimethylisoxazol-5-yl)piperazine4-[4-(2-fluoro-4-[ ${ }^{11}$ C]methylphenyl)thiazol-2-yl]-1-carboxamide $\left(\left[{ }^{11} \mathrm{C}\right] \mathrm{DFMC}\right)$ was developed as an irreversible-type positron emission tomography (PET) tracer for FAAH. Here, we attempted to noninvasively estimate rate constant $\mathrm{k}_{3}$ (rate of transfer to the specifically-bound compartment) as a direct index for $F A A H$ in the rat brain. First, the two-tissue compartment model analysis including three parameters $\left[\mathrm{K}_{1}-\mathrm{k}_{3}\right.$, two-tissue compartment model for the irreversible-type radiotracer (2TCMi)] in PET study with $\left[{ }^{11} \mathrm{C}\right]$ DFMC was conducted, which provided $0.21 \pm 0.04 \mathrm{ml} \cdot \mathrm{cm}^{-3} \cdot \mathrm{min}^{-1}$ of the net uptake value $\left(\mathrm{K}_{\mathrm{i}}\right)$, an indirect index for $\mathrm{FAAH}$, in the FAAHrichest region (the cingulate cortex). Subsequently, to noninvasively estimate $\mathrm{K}_{i}$ value, the reference model analysis (Patlak graphical analysis reference model) was tried using a time-activity curve of the spinal cord. In that result, the noninvasive $K_{i}$ value $\left(K^{R E F}\right)$ was concisely estimated with high correlation $(r>0.95)$ to $\mathrm{K}_{\mathrm{i}}$ values based on 2TCMi. Using estimated $\mathrm{K}^{\mathrm{REF}}$ value, we tried to obtain calculated- $\mathrm{k}_{3}$ based on previously defined equations.
The calculated $\mathrm{k}_{3}$ was successfully estimated with high correlation $(r=0.95)$ to direct $k_{3}$ in 2TCMi. Finally, the dose relationship study using calculated $\mathrm{k}_{3}$ demonstrated that in vivo $\mathrm{ED}_{50}$ value of [3-(3carbamoylphenyl)phenyl] $N$-cyclohexylcarbamate, a major inhibitor of $\mathrm{FAAH}$, was $66.4 \mu \mathrm{g} / \mathrm{kg}$ in rat brain. In conclusion, we proposed the calculated $k_{3}$ as an alternative index corresponding to regional FAAH concentrations and suggested that PET with $\left[{ }^{11} \mathrm{C}\right] \mathrm{DFMC}$ enables occupancy study for new pharmaceuticals targeting FAAH.

\section{SIGNIFICANCE STATEMENT}

In the present study, we proposed calculated $\mathrm{k}_{3}$ as an alternative index corresponding with fatty acid amide hydrolase concentration. By using calculated $k_{3}$, in vivo $E_{50}$ of [3-(3-carbamoylphenyl)phenyl] $N$-cyclohexylcarbamate was successfully estimated to be $66.4 \mu \mathrm{g} / \mathrm{kg}$ for rats. Thus, we demonstrated the pharmacological utility of positron emission tomography with $N$-(3,4-dimethylisoxazol-5-yl)piperazine-4-[4-(2-fluoro-4$\left[{ }^{11} \mathrm{C}\right]$ methylphenyl)thiazol-2-yl]-1-carboxamide.

\section{Introduction}

The endocannabinoid system is known as a key biologic system having retrograde neurotransmission in the central nervous system (Devane et al., 1992; Bayewitch et al., 1995) and has been reported to regulate a broad range of physiologic processes in multiple disorders, such as pain, neuroinflammation, anxiety, neurodegenerative disorders, cancer, epilepsy, and metabolic syndrome (Pacher et al., 2006). Endocannabinoids (anandamide and 2-arachidonoyl glycerol) are synthesized by

a Declaration of conflicting interests

The authors declared no potential conflicts of interest with respect to the research, authorship, and/or publication of this article.

https://doi.org/10.1124/jpet.119.263772.

S This article has supplemental material available at jpet.aspetjournals.org. several enzymes, depending on the intracellular $\mathrm{Ca}^{2+}$ concentration, on postsynaptic neurons and metabolized by fatty acid amide hydrolase (FAAH) and monoacylglycerol lipase (Piomelli, 2003; Ahn et al., 2008). Among the endocannabinoids, anandamide has important roles for the activation of microglia in neuroinflammation (Raboune et al., 2014; Malek et al., 2015). Moreover, a great deal of evidence from preclinical studies indicates that elevating anandamide concentrations through the inhibition of FAAH can mitigate pain and neuroinflammation (Schlosburg et al., 2009). Several FAAH inhibitors, classified as urea, carbamate, and keto-heterocycle derivatives, have been developed (Seierstad and Breitenbucher, 2008) and progressed to clinical trials to treat inflammatory pain, cannabis dependence, and schizophrenia (Kathuria et al., 2003; Li et al., 2012). Subsequently, to further understand the function of FAAH

ABBREVIATIONS: $\mathrm{BP}_{\mathrm{ND}}$, nondisplaceable binding potential; $\left[{ }^{11} \mathrm{C}\right] \mathrm{CURB},\left[{ }^{11} \mathrm{C}\right.$-carbonyl $]-6$-hydroxy-(1,1'-biphenyl)-3-yl cyclohexylcarbamate; $\left[{ }^{11} \mathrm{C}\right]$ DFMC, $N$-(3,4-dimethylisoxazol-5-yl)piperazine-4-[4-(2-fluoro-4-[ $\left[{ }^{11} \mathrm{C}\right]$ methylphenyl)thiazol-2-yl]-1-carboxamide; \%COV, percentage of coefficients of variation ${ }^{\mathrm{a}}$; $\mathrm{C}_{\mathrm{p}}$, plasma compartment; FAAH, fatty acid amide hydrolase; ICC, intraclass correlation coefficient; \%ID, percent injected dose; MRI,

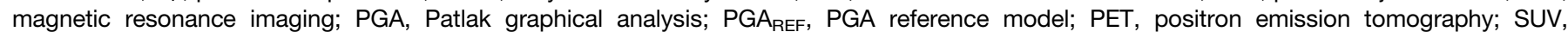
standardized uptake value; TAC, time-activity curve; 1TCM, one-tissue compartment model; 2TCMi, two-tissue compartment model for the irreversible-type radiotracer; URB597, [3-(3-carbamoylphenyl)phenyl] N-cyclohexylcarbamate. 
and to research drug kinetics in vivo, several positron emission tomography (PET) tracers for FAAH were synthesized based on the inhibitors (Wilson et al., 2011; Rotstein et al., 2014; Kumata et al., 2015; Shimoda et al., 2015, 2016) (Fig. 1).

PET is frequently used as an imaging modality or quantification tool for basic and clinical research to elucidate drug kinetics, molecular density, and distribution in vivo. In general, PET studies with reversible-type radiotracers can acquire the nondisplaceable binding potential $\left(\mathrm{BP}_{\mathrm{ND}}\right)$ as a reasonable index to estimate receptor density (Innis et al., 2007), which permits pharmacological applications, such as the measurement of dose-occupancy relationships for drugs (Saijo et al., 2009). To the best of our knowledge, although two reversible-type PET tracers for FAAH (Fig. 1A) have been developed, both tracers failed to estimate sufficient $\mathrm{BP}_{\mathrm{ND}}$ values (Liu et al., 2013; Wang et al., 2016). In contrast, PET studies with the irreversible-type radiotracer were generally conducted using two-tissue compartment model analysis with three parameters $\left[k_{4}=0\right.$, two-tissue compartment model for the irreversible-type radiotracer (2TCMi); Fig. 2]. Of the three parameters, the $\mathrm{k}_{3}$ consisted of $\mathrm{B}_{\max }$ multiplied by the association rate constant $\left(\mathrm{k}_{\mathrm{on}}\right)$ to the target molecule. Thus, estimated $\mathrm{k}_{3}$ gives the most important information for target molecules. Unfortunately, a directly estimated $\mathrm{k}_{3}$ is usually unstable because of including moderate stochastic varieties. Therefore, the macro parameter [e.g., net uptake value $\left(\mathrm{K}_{\mathrm{i}}\right)$ ] is often estimated as the stable quantitative index for target molecules in place of $\mathrm{BP}_{\mathrm{ND}}$ value (Egerton et al., 2010; Carter et al., 2012; Rusjan et al., 2013; Frick et al., 2015).

Recently, we have developed $N$-(3,4-dimethylisoxazol-5-yl) piperazine-4-[4-(2-fluoro-4-[ $\left.{ }^{11} \mathrm{C}\right]$ methylphenyl)thiazol-2-yl]1-carboxamide ( $\left.\left[{ }^{11} \mathrm{C}\right] \mathrm{DFMC}\right)$ (Fig. 1B), which has higher affinity for FAAH $\left(\mathrm{IC}_{50}=6.1 \mathrm{nM}\right)$ than the primary PET tracer $\left[{ }^{11} \mathrm{C}\right.$-carbonyl]-6-hydroxy-(1,1'-biphenyl)-3-yl cyclohexylcarbamate ([ $\left.{ }^{11} \mathrm{C}\right]$ CURB) $\left(\mathrm{IC}_{50}=30 \mathrm{nM}\right)$. Moreover, $\left[{ }^{11} \mathrm{C}\right] \mathrm{DFMC}$ showed high uptake in rat brain, and the radioactivity was irreversibly trapped (Shimoda et al., 2016).

A Reversible PET ligands

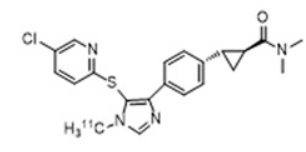

["C]MK-3168

B

Irreversible PET ligands

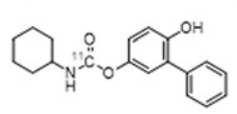

I"C]CURB

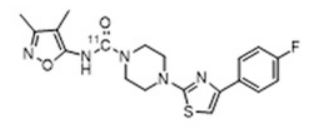

$1^{11} \mathrm{CJOPFC}$

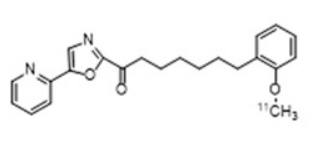

I $^{11}$ CIMPPO

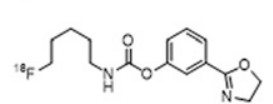

$I^{18}$ FIDOPP

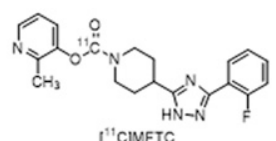

I"CJMFTC

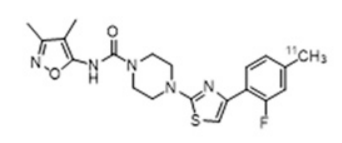

["CJPFMC
Fig. 1. Current PET tracers for FAAH imaging. (A) Reversible-type PET tracers. (B) Irreversible-type PET tracers.

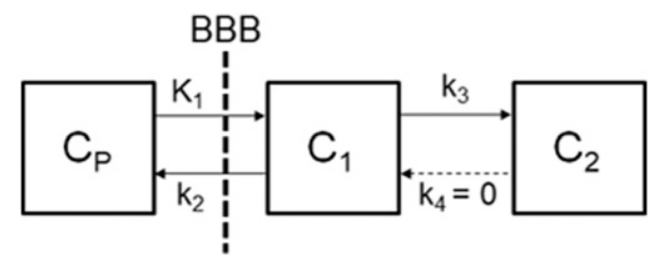

Fig. 2. Schematic of two-tissue compartment model for irreversible-type radiotracer. $\mathrm{C}_{\mathrm{P}}$ compartment represents free radiotracer in the plasma. $\mathrm{C}_{1}$ compartment expresses free and nonspecific binding of radiotracer in brain tissue past the blood-brain barrier (BBB). $\mathrm{C}_{2}$ compartment displays specific binding of radiotracer with target molecule. $K_{1}$ and $k_{2}$ describe the influx and efflux rates of radiotracer between $C_{P}$ and $C_{1} \cdot k_{3}$ and $k_{4}$ exhibit the association and dissociation rates of radiotracer to target molecule.

In our study, we first conducted a quantitative PET analysis with blood sampling to estimate the kinetic parameters of $\left[{ }^{11} \mathrm{C}\right] \mathrm{DFMC}$ in various brain regions of the rat. Subsequently, we attempted to noninvasively estimate the net uptake value $\left(\mathrm{K}^{\mathrm{REF}}\right)$ using a reference tissue model and aimed to establish an alternative index for the direct relationship with FAAH concentrations. Finally, to demonstrate the pharmacological utility of PET with $\left[{ }^{11} \mathrm{C}\right] \mathrm{DFMC}$, we attempted to measure the $\mathrm{ED}_{50}$ of [3-(3-carbamoylphenyl)phenyl] $N$-cyclohexylcarbamate (URB597), a clinically used inhibitor of FAAH, using PET with $\left[{ }^{11} \mathrm{C}\right] \mathrm{DFMC}$ in vivo.

\section{Materials and Methods}

\section{General}

All chemical reagents and organic solvents were purchased from Sigma-Aldrich (St. Louis, MO), FUJIFILM Wako Pure Chem. (Osaka, Japan), or Nacalai Tesque (Kyoto, Japan) and used without further purification. The commercially available compound URB597 ( $\geq 98 \%$ purity) was purchased from Sigma-Aldrich and dissolved in saline containing $10 \%$ ethanol and 5\% Tween 20 for animal experiments. ${ }^{11} \mathrm{C}$ was produced using a cyclotron (CYPRIS HM-18; Sumitomo Heavy Industries, Tokyo, Japan). All radioactive values were used with decay correction (a half-life of ${ }^{11} \mathrm{C}: 20.4$ minutes) (Lederer et al., 1967).

\section{Subjects}

Male Sprague-Dawley rats ( $7-10$ weeks old, $n=30$ ) were purchased from Japan SLC (Shizuoka, Japan), housed in a temperaturecontrolled environment with a 12-hour light/dark cycle, and fed a standard diet. All animal experiments were performed according to the recommendations specified by the Committee for the Care and Use of Laboratory Animals of the National Institutes for Quantum and Radiologic Science and Technology and Animal Research: Reporting of In Vivo Experiments guidelines.

\section{Radiotracer}

$\left.{ }^{[1} \mathrm{C}\right] \mathrm{DFMC}$ was synthesized according to a previous report (Shimoda et al., 2016). Briefly, $\left[{ }^{11} \mathrm{C}\right] \mathrm{DFMC}$ was synthesized using a $\mathrm{C}-{ }^{11} \mathrm{C}$ coupling reaction of an aryl boronic ester precursor with $\left[{ }^{11} \mathrm{C}\right]$ methyl iodide in the presence of a Pd catalyst. Over $370 \mathrm{MBq}$ of $\left[{ }^{11} \mathrm{C}\right] \mathrm{DFMC}$ was obtained with radiochemical purity of $>99 \%$ and molar activity of $>37 \mathrm{GBq} / \mu \mathrm{mol}$.

\section{PET Study}

PET Analysis with Blood Sampling. Prior to the PET scan, a rat $(n=4 ; 309 \pm 14 \mathrm{~g})$ was implanted with a polyethylene catheter (FR2; Imamura, Tokyo, Japan) inserted into the left femoral artery for blood sampling. Subsequently, the rat was secured in a custom-designed chamber and placed in a small-animal PET 
scanner (Inveon; Siemens Medical Solutions, Knoxville, TN). Body temperature was maintained using a $40^{\circ} \mathrm{C}$ water circulation system (T/Pump TP401; Gaymar Industries, Orchard Park, NY). A 24-gauge intravenous catheter (Terumo Medical Products, Tokyo, Japan) was placed into the tail vein of the rat. A bolus of $\left[{ }^{11} \mathrm{C}\right] \mathrm{DFMC}(1 \mathrm{ml}, 52-57 \mathrm{MBq}$, $0.3-0.9 \mathrm{nmol}$ ) was injected at a flow rate of $0.5 \mathrm{ml} / \mathrm{min}$ via a tail vein catheter. Dynamic emission scans in three-dimensional list mode were performed for 90 minutes ( 10 second $\times 12$ frames, 20 seconds $\times 3$ frames, 30 seconds $\times 3$ frames, 60 seconds $\times 3$ frames, 150 seconds $\times 3$ frames, and 300 seconds $\times 15$ frames). The acquired PET dynamic images were reconstructed by filtered back projection using a Hanning's filter with a Nyquist cutoff of 0.5 cycle/pixel. The time-activity curves (TACs) of $\left[{ }^{11} \mathrm{C}\right]$ DFMC were acquired from volumes of interest in the cingulate cortex, striatum (caudate/putamen), hippocampus, thalamus, hypothalamus, pons, and cerebellum by referring to a rat brain magnetic resonance imaging (MRI) template using PMOD software (version 3.4; PMOD technology, Zurich, Switzerland). The radioactivity was decay corrected to the injection time and is expressed as the standardized uptake value (SUV).

For the blocking study, a rat $(281 \mathrm{~g})$ cannulated as described above was intravenously injected with URB597 at a concentration of $3 \mathrm{mg} / \mathrm{kg}$ $(0.28 \mathrm{ml}$ vehicle) via the tail vein catheter while under anesthesia. After 30 minutes of anesthesia, a PET assessment with $\left[{ }^{11} \mathrm{C}\right] \mathrm{DFMC}$ (56 MBq; $1.6 \mathrm{nmol}$ ) was conducted as described above. volumes of interest were drawn on the spinal cord in addition to general regions.

For counting radioactivity, blood samples were manually collected into microtubes containing heparin $(1 \mu \mathrm{l})$ at intervals of 20 seconds $(0.05 \mathrm{ml}$ for 120 seconds) and $0.5(0.05 \mathrm{ml}$ for 1 minute $), 1$ ( $0.05 \mathrm{ml}$ for 2 minutes), 5 (0.08 $\mathrm{ml}$ for 10 minutes), $30(0.3 \mathrm{ml}), 60(0.4 \mathrm{ml})$, and 90 minutes $(0.5 \mathrm{ml})$ after initiation of the PET scan. Blood samples were centrifuged at $15,000 \mathrm{~g}$ at $4^{\circ} \mathrm{C}$ to separate the plasma. The radioactivity in the whole blood and plasma was measured by a 1480 Wizard autogamma scintillation counter (PerkinElmer, Waltham, MA). The radioactivity was corrected for decay. For metabolite analysis, six plasma samples were separated at $1(0.02 \mathrm{ml}), 5(0.02 \mathrm{ml}), 15(0.05$ $\mathrm{ml}), 30(0.1 \mathrm{ml}), 60(0.2 \mathrm{ml})$, and 90 minutes $(0.3 \mathrm{ml})$ after the injection.

Metabolite analysis was performed as described previously (Yamasaki et al., 2014). Briefly, whole blood samples were treated to separate the plasma, which was deproteinized with an equivalent amount of acetonitrile. An aliquot of the supernatant obtained from the plasma was analyzed using a high-performance liquid chromatography system with a radiation detector (Takei et al., 2001). Plasma protein binding was not determined in our study. The time curves for a fraction of unchanged $\left[{ }^{11} \mathrm{C}\right] \mathrm{DFMC}$ in the plasma were fitted using three exponential equations and subsequently used for kinetic analyses.

Test-Retest PET Studies. Four rats were used twice within 7 days $(285 \pm 7 \mathrm{~g}$ at first and $323 \pm 9 \mathrm{~g}$ at the second scan) for PET assessments with $\left[{ }^{11} \mathrm{C}\right] \mathrm{DFMC}(47-61 \mathrm{MBq} ; 0.5-0.8 \mathrm{nmol})$, and the reliability of the data was assessed using the intraclass correlation coefficient (ICC). The parameters were calculated as follows:

1. Relative difference $(\%)=(\operatorname{scan} 2-\operatorname{scan} 1) /$ scan $1 \times 100$

2. Test-retest variability $(\%)=\mid$ scan $2-\operatorname{scan} 1 \mid /[($ scan $2+$ scan 1$) / 2] \times 100$

3. Percentage of coefficients of variation $(\% \mathrm{COV})=$ S.D./mean $\times 100$

4. ICC with BSMSS as "mean sum of squares between subjects" and WSMSS as "mean sum of squares within subjects": ICC = (BSMSS - WSMSS)/(BSMSS + WSMSS). An ICC value of -1 denotes no reliability, whereas a value of 1 indicates maximum reliability (Elmenhorst et al., 2012).

\section{Theory}

Compartment Model Analysis for Irreversible-Type PET Tracers. To estimate kinetic parameters in PET with $\left[{ }^{11} \mathrm{C}\right] \mathrm{DFMC}$,
2TCMi (Fig. 2) was conducted. Each rate constant was derived from the following equations:

$$
\begin{gathered}
\mathrm{K}_{1}=\mathrm{FE}, \\
\mathrm{k}_{2}=\mathrm{K}_{1} / \mathrm{V}_{\mathrm{d}}=\mathrm{FE} / \mathrm{V}_{\mathrm{d}}, \\
\mathrm{k}_{3}=\mathrm{f}_{\mathrm{ND}} \mathrm{k}_{\text {on }} \mathrm{B}_{\max },
\end{gathered}
$$

in which $K_{1}$ describes the influx rate of radiotracer from the plasma compartment $\left(\mathrm{C}_{\mathrm{P}}\right)$ to the free and nonspecific compartment $\left(\mathrm{C}_{1}\right) ; \mathrm{k}_{2}$ represents the efflux rate of radioligand from $\mathrm{C}_{1}$ to $\mathrm{C}_{\mathrm{P}} ; \mathrm{k}_{3}$ describes the transfer from $\mathrm{C}_{1}$ to the specific-bound compartment $\left(\mathrm{C}_{2}\right) . \mathrm{F}$ is the blood flow, $\mathrm{E}$ is the first pass extraction factor, $\mathrm{V}_{\mathrm{d}}$ is the distribution volume of the radiotracer in the $\mathrm{C}_{1}$ compartment, $f_{N D}$ is the tissue-free fraction, $k_{\text {on }}$ is the $\left[{ }^{11} \mathrm{C}\right]$ DFMC-FAAH association rate constant, and $B_{\max }$ is the concentration of FAAH. In addition, the $\mathrm{K}_{\mathrm{i}}$ as the quantitative index for the net uptake volume of $\left[{ }^{11} \mathrm{C}\right] \mathrm{DFMC}$ with $\mathrm{FAAH}$ was determined as follows:

$$
K_{i}=\frac{K_{1} k_{3}}{k_{2}+k_{3}}
$$

To compare the accuracy of $\mathrm{K}_{\mathrm{i}}$ values based on $2 \mathrm{TCM}_{\mathrm{i}}\left(\mathrm{K}_{\mathrm{i}}^{2 \mathrm{TCMi}}\right)$, Patlak graphical analysis (PGA) (Patlak et al., 1983) with linear regression was also performed (the slope of a regression line in PGA theoretically equals the $\mathrm{K}_{\mathrm{i}}$ value).

A Reference Tissue Model for Irreversible-Type PET Tracers. When reference tissue can be employed, the application of PGA as a reference method [PGA reference model $\left(\mathrm{PGA}_{\mathrm{REF}}\right)$ ] is possible (Patlak and Blasberg, 1985). In this case, the procedure merely replaces $\mathrm{C}_{\mathrm{P}}(\mathrm{t})$ by $\mathrm{TAC}$ in the reference tissue. In accordance with a previous report (Patlak and Blasberg, 1985), the slope in graphical analysis reflects the following relation:

$$
\text { Slope }=K^{R E F}=\frac{K_{1} k_{3}}{k_{2}+k_{3}} \times \frac{k_{2}^{\prime}}{K_{1}^{\prime}\left(1+K_{e q}^{\prime}\right)},
$$

in which, $\mathrm{K}_{1}{ }^{\prime}, \mathrm{k}_{2}{ }^{\prime}$, and $\mathrm{K}_{\mathrm{eq}}{ }^{\prime}$ indicate input rate, output rate, and equilibrium constant in the reference area, respectively. In the reference region without irreversible binding, it may be reasonable to assume that $\mathrm{K}_{\mathrm{eq}}{ }^{\prime}=0$ (Patlak and Blasberg, 1985).

Here, $\frac{k_{2}^{\prime}}{K_{1}^{\prime}}$ is replaced as A,

$$
K^{R E F}=A \frac{K_{1} k_{3}}{k_{2}+k_{3}}=A \times K_{i} .
$$

Noninvasive Estimation of the Alternative $\mathbf{k}_{3}$ Value Based on the $\mathbf{K}^{\mathbf{R E F}}$ Value. In this study, we attempted to noninvasively estimate the alternative $\mathrm{k}_{3}$ (defined as calculated $\mathrm{k}_{3}$ ) values, since the $\mathrm{K}^{\mathrm{REF}}$ value is an indirect index for FAAH concentration. Calculated $\mathrm{k}_{3}$ is induced by modifying eq. 6 .

$$
\text { Calculated } k_{3}=\frac{K^{R E F} k_{2}}{A K_{1}-K^{R E F}}
$$

Here, the regional $\mathrm{K}_{1}$ and $\mathrm{k}_{2}$ values were fixed by averaged values in 2TCMi analyses $(n=4)$. The constant A was also displaced as follows:

$$
\text { Constant } A=\frac{K^{R E F}}{K_{i}} .
$$

\section{Conditions for the Use of Calculated $k_{3}$ Values}

In this study, we proposed a calculated $\mathrm{k}_{3}$ as a new quantitative index for FAAH concentrations. However, there are several conditions for the use of calculated $\mathrm{k}_{3}$, which are as follows: 


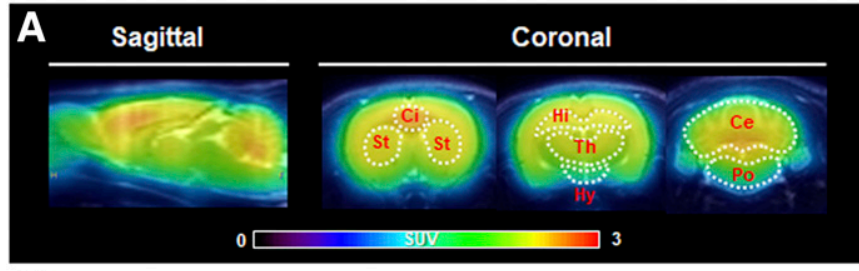

B

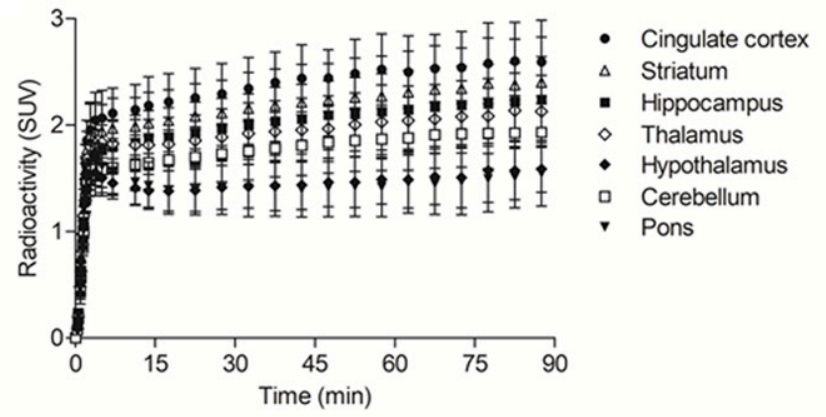

Fig. 3. Representative PET/MRI-fused images (A) and time-activity curves $(\mathrm{B})$ of $\left[{ }^{11} \mathrm{C}\right] \mathrm{DFMC}$ in brain regions $(n=4)$. PET images were summed between 0 to 90 minutes of acquisition data. The radioactivity was expressed by SUV. Ce, cerebellum; Ci, cingulate cortex; Hi, hippocampus; Hy, hypothalamus; Po, pons; St, striatum; Th, thalamus.

1. To estimate averaged $K_{1}, k_{2}$, and constant $A$, several repeated PET assessments with blood sampling and compartment model analyses are essential in advance of these estimates.

2. It is required that there are no differences in influx $\left(\mathrm{K}_{1}\right)$ and efflux $\left(\mathrm{k}_{2}\right)$ rates of radiotracer between the research subject and the baseline subject.

3. The calculated $k_{3}$ remains an unstable value and therefore includes a specific variation based on individual differences. To surmount this disadvantage, several samples sizes $(n \geq 3$, at least) should be considered.

Although there are several limitations, it would be valuable to consider whether calculated $\mathrm{k}_{3}$ can be adapted because calculated $\mathrm{k}_{3}$ in multidose response assays using PET could be more easily obtained than direct $\mathrm{k}_{3}$ with blood sampling.

\section{Multidose URB597 Treatment-Response Assays}

A series of dynamic PET scans ([ $\left[{ }^{11} \mathrm{C}\right] \mathrm{DFMC}$ : $38-60 \mathrm{MBq}$; $\left.0.3-1.0 \mathrm{nmol}\right)$ without blood sampling were performed for each rat $(n=3$ for each dose; $241-319$ g) 30 minutes after administration with different doses of URB597 (0.003, 0.01, 0.03, 0.1, 0.3, 1 , and $3 \mathrm{mg} / \mathrm{kg}$ in $0.3-\mathrm{ml}$ vehicle).
The results of the inhibitory experiments were subjected to nonlinear regression analysis using Prism 5 (GraphPad Software, La Jolla, CA), and $\mathrm{ED}_{50}$ values of URB597 were calculated using each averaged calculated $\mathrm{k}_{3}$ value of several brain regions (cingulate cortex, striatum, hippocampus, thalamus, and cerebellum).

\section{Statistical Methods}

Goodness of fit was evaluated using the Akaike information criterion (Akaike, 1974) and the model selection criterion (Handbook, 1995). Values are given as mean \pm S.D. The $\%$ COV was estimated from the diagonal of the covariance matrix of the fitting. All data analyses were performed using GraphPad Prism v5.0 (GraphPad Software).

\section{Results}

Invasive Quantitative PET Analysis Using $\left[{ }^{11} \mathrm{C}\right]$ DFMC. Figure 3 show representative averaged PET/MRI images (A) and TACs (B) in brain regions. High uptake of radioactivity was detected in the cingulate cortex and striatum (caudate/putamen), and moderate radioactivity was detected in the hippocampus, thalamus, cerebral cortex, and cerebellum. Meanwhile, radioactivity in the hypothalamus and pons was relatively low. These radioactive distribution patterns corresponded with the distribution of FAAH concentrations (Thomas, et al., 1997). TACs in FAAH-rich brain regions constantly increased without clearance after the injection of $\left[{ }^{11} \mathrm{C}\right] \mathrm{DFMC}$.

Figure 4A shows the metabolite-corrected plasma input function of $\left[{ }^{11} \mathrm{C}\right] \mathrm{DFMC}$. The unchanged $\left[{ }^{11} \mathrm{C}\right] \mathrm{DFMC}$ in the arterial plasma peaked at $4.19 \pm 0.72$ SUV 2 minutes after the injection and declined to $0.35 \pm 0.03$ SUV 5 minutes after the injection and $0.04 \pm 0.01$ SUV 90 minutes after the injection. The metabolic rate of $\left[{ }^{11} \mathrm{C}\right] \mathrm{DFMC}$ was relatively slow: $>65 \%$ of the parent compound remained 30 minutes after the injection, and roughly $30 \%$ of the parent compound remained 90 minutes after the injection.

Figure $4 \mathrm{~B}$ shows TACs with a one-tissue compartment model (1TCM) containing $\mathrm{C}_{\mathrm{P}}$ and $\mathrm{C}_{1}$ compartments only, and 2TCMi fitting curves in the cingulate cortex. The 1TCM showed a poorly fitting curve for TACs. Conversely, the fitting curve for 2TCMi showed a good shape and indicated good scores (see Supplemental Table 1) regarding the goodness of fit. Thus, the 2TCMi is an adequate kinetic model for this radiotracer. Detailed full kinetic parameters in brain regions are shown in Table 1 . Of the rate constants, the directly estimated $\mathrm{k}_{3}$ values were acquired as $0.08-0.18$ minutes $^{-1}$
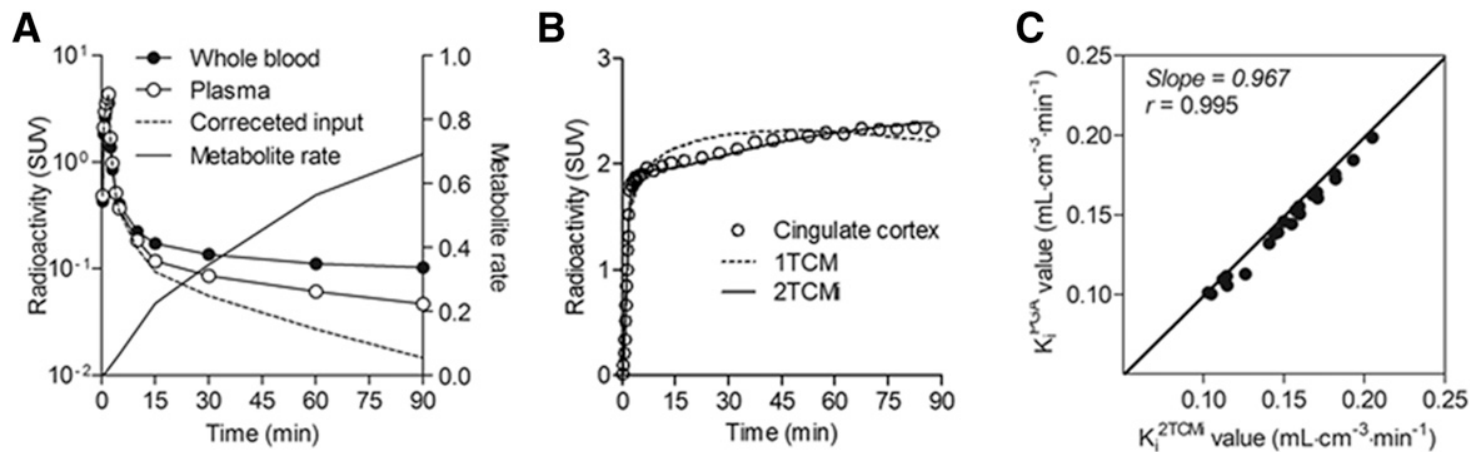

Fig. 4. Curve-fitting analysis using input function in PET with $\left[{ }^{11} \mathrm{C}\right] \mathrm{DFMC}$. (A) Plasma input curves of $\left[{ }^{11} \mathrm{C}\right] \mathrm{DFMC}$. (B) Comparison between 1 TCM and $2 \mathrm{TCMi}$ curve fittings of data from the cingulate cortex. (C) Correlation plots between $\mathrm{K}_{\mathrm{i}}$ values based on $2 \mathrm{TCMi}$ and $\mathrm{K}_{\mathrm{i}}$ values based on PGA in rat brains $(n=4)$. 
TABLE 1

Kinetic rate constants estimated with 2 TCMi in PET with $\left[{ }^{11} \mathrm{C}\right] \mathrm{DFMC}(n=4$, mean \pm S.D. $)$ The $\%$ COV was expressed within parentheses.

\begin{tabular}{|c|c|c|c|c|c|c|c|}
\hline Regions & $\mathrm{K}_{1}\left(\mathrm{ml} \cdot \mathrm{cm}^{-3} \cdot \mathrm{min}^{-1}\right)$ & $\mathrm{k}_{2}\left(\min ^{-1}\right)$ & $\mathrm{k}_{3}\left(\min ^{-1}\right)$ & $\mathrm{K}_{1} / \mathrm{k}_{2}\left(\mathrm{ml} \cdot \mathrm{cm}^{-3}\right)$ & $\lambda \mathrm{k}_{3}\left(\mathrm{ml} \cdot \mathrm{cm}^{-3} \cdot \min ^{-1}\right)$ & $\mathrm{K}_{\mathrm{i}}\left(\mathrm{ml} \cdot \mathrm{cm}^{-3} \cdot \mathrm{min}^{-1}\right)$ & Patlak $\mathrm{K}_{\mathrm{i}}\left(\mathrm{ml} \cdot \mathrm{cm}^{-3} \cdot \mathrm{min}^{-1}\right)$ \\
\hline Cingulate cortex & $\begin{array}{c}0.32 \pm 0.06 \\
(1.4 \pm 0.1)\end{array}$ & $\begin{array}{c}0.09 \pm 0.03 \\
(12.9 \pm 2.3)\end{array}$ & $\begin{array}{c}0.18 \pm 0.04 \\
(9.5 \pm 2.2)\end{array}$ & $\begin{array}{c}3.62 \pm 0.69 \\
(11.4 \pm 2.2)\end{array}$ & $\begin{array}{c}0.62 \pm 0.12 \\
(15.9 \pm 3.2)\end{array}$ & $\begin{array}{c}0.21 \pm 0.04 \\
(0.0 \pm 0.1)\end{array}$ & $\begin{array}{c}0.21 \pm 0.04 \\
(0.8 \pm 0.1)\end{array}$ \\
\hline Striatum & $\begin{array}{c}0.31 \pm 0.06 \\
(1.4 \pm 0.2)\end{array}$ & $\begin{array}{c}0.10 \pm 0.02 \\
(9.7 \pm 1.5)\end{array}$ & $\begin{array}{c}0.16 \pm 0.03 \\
(7.2 \pm 1.3)\end{array}$ & $\begin{array}{l}3.37 \pm 0.75 \\
(8.5 \pm 1.4)\end{array}$ & $\begin{array}{c}0.53 \pm 0.17 \\
(15.6 \pm 2.7)\end{array}$ & $\begin{array}{c}0.20 \pm 0.04 \\
(0.2 \pm 0.2)\end{array}$ & $\begin{array}{c}0.19 \pm 0.05 \\
(0.5 \pm 0.1)\end{array}$ \\
\hline Hippocampus & $\begin{array}{c}0.27 \pm 0.05 \\
(1.1 \pm 0.1)\end{array}$ & $\begin{array}{c}0.08 \pm 0.03 \\
(9.0 \pm 1.5)\end{array}$ & $\begin{array}{c}0.16 \pm 0.04 \\
(6.7 \pm 1.4)\end{array}$ & $\begin{array}{l}3.49 \pm 0.88 \\
(8.0 \pm 1.5)\end{array}$ & $\begin{array}{c}0.56 \pm 0.18 \\
(14.7 \pm 2.9)\end{array}$ & $\begin{array}{c}0.18 \pm 0.04 \\
(0.0 \pm 0.2)\end{array}$ & $\begin{array}{c}0.18 \pm 0.04 \\
(0.4 \pm 0.1)\end{array}$ \\
\hline Thalamus & $\begin{array}{c}0.30 \pm 0.05 \\
(1.2 \pm 0.2)\end{array}$ & $\begin{array}{c}0.10 \pm 0.02 \\
(7.3 \pm 1.7)\end{array}$ & $\begin{array}{c}0.13 \pm 0.02 \\
(5.5 \pm 1.4)\end{array}$ & $\begin{array}{c}3.11 \pm 0.46 \\
(6.3 \pm 1.5)\end{array}$ & $\begin{array}{c}0.42 \pm 0.12 \\
(11.8 \pm 2.9)\end{array}$ & $\begin{array}{c}0.17 \pm 0.04 \\
(0.3 \pm 0.1)\end{array}$ & $\begin{array}{c}0.17 \pm 0.04 \\
(0.7 \pm 0.2)\end{array}$ \\
\hline Hypothalamus & $\begin{array}{c}0.27 \pm 0.04 \\
(1.8 \pm 0.3)\end{array}$ & $\begin{array}{c}0.13 \pm 0.01 \\
(8.5 \pm 1.9)\end{array}$ & $\begin{array}{c}0.12 \pm 0.02 \\
(6.5 \pm 1.5)\end{array}$ & $\begin{array}{c}2.07 \pm 0.20 \\
(7.0 \pm 1.6)\end{array}$ & $\begin{array}{r}0.25 \pm 0.07 \\
(13.5 \pm 3.1)\end{array}$ & $\begin{array}{c}0.13 \pm 0.03 \\
(0.8 \pm 0.2)\end{array}$ & $\begin{array}{c}0.12 \pm 0.03 \\
(1.8 \pm 0.7)\end{array}$ \\
\hline Cerebellum & $\begin{array}{c}0.26 \pm 0.05 \\
(1.4 \pm 0.1)\end{array}$ & $\begin{array}{c}0.11 \pm 0.03 \\
(8.9 \pm 1.3)\end{array}$ & $\begin{array}{c}0.16 \pm 0.03 \\
(6.6 \pm 1.3)\end{array}$ & $\begin{array}{c}2.58 \pm 0.63 \\
(7.8 \pm 1.3)\end{array}$ & $\begin{array}{c}0.42 \pm 0.11 \\
(14.4 \pm 2.5)\end{array}$ & $\begin{array}{c}0.16 \pm 0.03 \\
(0.1 \pm 0.1)\end{array}$ & $\begin{array}{c}0.15 \pm 0.03 \\
(0.5 \pm 0.3)\end{array}$ \\
\hline Pons & $\begin{array}{c}0.28 \pm 0.04 \\
(1.2 \pm 0.2)\end{array}$ & $\begin{array}{c}0.11 \pm 0.01 \\
(5.6 \pm 1.2)\end{array}$ & $\begin{array}{l}0.08 \pm 0.01 \\
(4.6 \pm 1.5)\end{array}$ & $\begin{array}{l}2.58 \pm 0.54 \\
(4.6 \pm 1.0)\end{array}$ & $\begin{array}{c}0.22 \pm 0.08 \\
(9.3 \pm 2.0)\end{array}$ & $\begin{array}{c}0.12 \pm 0.03 \\
(0.7 \pm 0.2)\end{array}$ & $\begin{array}{c}0.12 \pm 0.03 \\
(1.3 \pm 0.9)\end{array}$ \\
\hline
\end{tabular}

with $4.6 \%-9.5 \% \mathrm{COV}$ in the regions of interest. The macroparameter $\mathrm{K}_{\mathrm{i}}$ values for the quantitative uptake value of $\left[{ }^{11} \mathrm{C}\right]$ DFMC were obtained as $0.12-0.21 \mathrm{ml} \cdot \mathrm{cm}^{-3} \cdot \mathrm{min}^{-1}$ with $0.0 \%-0.8 \% \mathrm{COV}$ in the investigated brain regions.

Next, to validate the accuracy of the estimated $K_{i}$ values based on the compartmental analysis $\left(\mathrm{K}_{\mathrm{i}}^{2 \mathrm{TCMi}}\right)$, we compared these values with those based on graphical analysis $\left(\mathrm{K}_{\mathrm{i}}^{\mathrm{PGA}}\right)$, as shown in Fig. 4C. The slope of the resulting regression line was almost $1(0.967)$ and the $r$-value was 0.995 . These results indicate a high correlation between $\mathrm{K}_{\mathrm{i}}^{\mathrm{PGA}}$ and $\mathrm{K}_{\mathrm{i}}^{2 \mathrm{TCMi}}$ values, which suggests that $\mathrm{K}_{\mathrm{i}}^{2 \mathrm{TCMi}}$ values were estimated with high reliability.

Validation Studies for the PGA Reference Model. Figure 5, A and B show representative PET-averaged images (A) and TACs (B) in the cingulate cortex and spinal cord of rats pretreated with or without URB597 (3 mg/kg). Radioactivity in the cingulate cortex of the baseline subject was accumulated at a high level without clearance during the PET scan, which was significantly decreased by pretreatment with URB597. Meanwhile, uptake of radioactivity between the baseline and blocking subjects showed no significant differences $(P=0.106)$ in the spinal cord (Fig. 5B), which suggests that the spinal cord adequately serves as the reference region.

Subsequently, to noninvasively estimate net uptake values (defined as $\mathrm{K}^{\mathrm{REF}}$ ), we performed the PGA $\mathrm{REF}_{\mathrm{RE}}$ using the TAC of the spinal cord as a reference region. The validity of $\mathrm{K}^{\mathrm{REF}}$ values was evaluated by comparing with $\mathrm{K}_{\mathrm{i}}^{2 \mathrm{TCMi}}$ values. Figure $5 \mathrm{C}$ shows the relationship between the averaged $\mathrm{K}^{\mathrm{REF}}$ and $\mathrm{K}_{\mathrm{i}}^{2 \mathrm{TCMi}}$ values in baseline subjects $(n=4)$. The slope $\left(\mathrm{k}_{2}{ }^{\prime} / \mathrm{K}_{1}{ }^{\prime}\right.$, defined as constant A, see eq. 8) of the regression line was 0.075 with high correlation $(r=0.981, P<0.001)$ and a small intercept $(-0.004)$.

Additionally, to support the accuracy of $\mathrm{K}^{\mathrm{REF}}$ estimations, the reproducibility of the $\mathrm{K}^{\mathrm{REF}}$ values was evaluated by a testretest study using PET with $\left[{ }^{11} \mathrm{C}\right] \mathrm{DFMC}$. Table 2 shows the reproducibility of the test-retest PET study for the estimation of $\mathrm{K}^{\mathrm{REF}}$. In the cingulate cortex, the FAAH-richest region in the brain, the percentage of variability, ICC, and Pearson's $r$ were $8.8,0.836$, and 0.900 , respectively. Additionally, the correlation (Pearson's $r$ ) between test and retest outcomes in all regions of interest was 0.891 , indicating high reproducibility of $\mathrm{K}^{\mathrm{REF}}$ values after PET with $\left[{ }^{11} \mathrm{C}\right] \mathrm{DFMC}$.

Estimation for Calculated $\mathbf{k}_{\mathbf{3}}$ Values. The $\mathrm{K}^{\mathrm{REF}}$ value is an indirect index of FAAH concentration due to the macroparameter containing $\mathrm{K}_{1}, \mathrm{k}_{2}$, and $\mathrm{k}_{3}$ rate constants.
We attempted to noninvasively estimate an alternative $\mathrm{k}_{3}$ value (defined as calculated $k_{3}$ ) by inserting measured $\mathrm{K}^{\mathrm{REF}}$ values, constant $\mathrm{A}$, and fixed values (averaged $\mathrm{K}_{1}$ and $\mathrm{k}_{2}$ values in $2 \mathrm{TCMi}$ ). Here, because $\mathrm{K}^{\mathrm{REF}}$ values included a small bias $(-0.004)$ compared with $\mathrm{K}_{\mathrm{i}}^{2 \mathrm{TCMi}}$ values as described above (Fig. 5C), we modified eq. 7 as follows:

$$
\text { Calculated } k_{3}=\frac{\left(K^{R E F}-\text { bias }\right) k_{2}}{A K_{1}-\left(K^{R E F}-\text { bias }\right)} .
$$
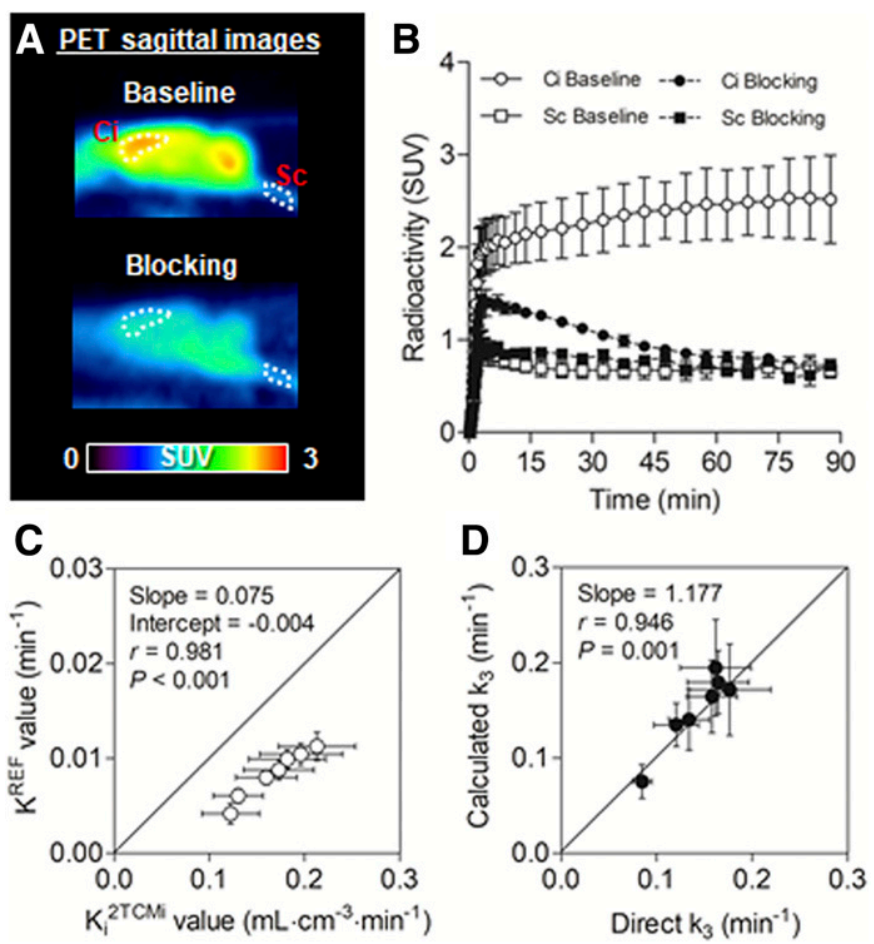

Fig. 5. Validation study for the use of the reference model. (A) Representative PET images of the baseline (top) and blocking (bottom, pretreatment with URB597 of $3 \mathrm{mg} / \mathrm{kg}$ ) rats. (B) Time-activity curves of $\left[{ }^{11} \mathrm{C}\right] D F M C$ in the cingulate cortex $(\mathrm{Ci})$ and spinal cord $(\mathrm{Sc})$ of the baseline $(n=4)$ and blocking $(n=3)$ rats. (C) Correlation plots between averaged $\mathrm{K}^{\mathrm{REF}}$ value based on $\mathrm{PGA}_{\mathrm{REF}}$ and the averaged $\mathrm{K}_{\mathrm{i}}$ value based on $2 \mathrm{TCMi}$ in rat brains $(n=4)$. (D) The relationship between an averaged calculated $\mathrm{k}_{3}$ value (estimating from measured $\mathrm{K}^{\mathrm{REF}}$, constant $\mathrm{A}$, averaged $\mathrm{K}_{1}, \mathrm{k}_{2}$, and the bias of reference region) and averaged direct $k_{3}$ values in the compartment model analysis. 
TABLE 2

Reliability of outcome parameters in test-retest PET studies with $\left[{ }^{11} \mathrm{C}\right] \mathrm{DFMC}(n=4)$

\begin{tabular}{|c|c|c|c|c|c|c|}
\hline \multirow{2}{*}{ Region } & \multicolumn{2}{|c|}{$\mathrm{K}^{\mathrm{REF}}$ value $\left(\min ^{-1}\right)$} & \multirow{2}{*}{ Relative Difference (\%) (Mean \pm S.D.) } & \multirow{2}{*}{$\%$ Variability (Mean \pm S.D.) } & \multirow{2}{*}{ ICC } & \multirow{2}{*}{ Pearson's $r$} \\
\hline & Test (Mean \pm S.D. $)$ & Retest (Mean \pm S.D.) & & & & \\
\hline Cingulate cortex & $0.0108 \pm 0.0021$ & $0.0100 \pm 0.0026$ & $-7.3 \pm 10.3$ & $8.8 \pm 10.8$ & 0.836 & 0.900 \\
\hline Striatum & $0.0092 \pm 0.0027$ & $0.0093 \pm 0.0017$ & $5.3 \pm 21.4$ & $11.8 \pm 13.6$ & 0.835 & 0.909 \\
\hline Hippocampus & $0.0098 \pm 0.0025$ & $0.0095 \pm 0.0011$ & $1.3 \pm 22.5$ & $15.0 \pm 10.9$ & 0.681 & 0.892 \\
\hline Thalamus & $0.0081 \pm 0.0023$ & $0.0077 \pm 0.0009$ & $-1.5 \pm 20.0$ & $14.8 \pm 9.1$ & 0.700 & 0.976 \\
\hline Hypothalamus & $0.0045 \pm 0.0018$ & $0.0041 \pm 0.0016$ & $7.8 \pm 76.8$ & $47.2 \pm 36.3$ & 0.430 & 0.226 \\
\hline Cerebellum & $0.0080 \pm 0.0024$ & $0.0078 \pm 0.0014$ & $2.9 \pm 24.9$ & $15.3 \pm 14.4$ & 0.735 & 0.795 \\
\hline Pons & $0.0040 \pm 0.0015$ & $0.0030 \pm 0.0011$ & $-18.8 \pm 41.7$ & $45.5 \pm 23.7$ & 0.369 & 0.304 \\
\hline
\end{tabular}

Figure 5D exhibits the relationship between averaged calculated $\mathrm{k}_{3}$ and the directly estimated $\mathrm{k}_{3}$ values. Although both $\mathrm{k}_{3}$ values were robust, the slope of the regression line was 1.177 and showed high correlation $(r=0.946, P=0.001)$. This result suggested that the calculated $\mathrm{k}_{3}$ value would be useful as a direct index of FAAH concentration.

Estimation for ED $_{50}$ of URB597 Using Calculated $\mathbf{k}_{3}$. Figure 6 shows representative PET/MRI images (A) of rat brains treated with multiple doses of URB597 and dose responses of calculated $\mathrm{k}_{3}$ values $(\mathrm{B})$ in the cingulate cortex, striatum, hippocampus, thalamus, and cerebellum. Radioactivity in all brain regions was gradually decreased by increasing the URB597 doses (Fig. 6A). Treatment with $1 \mathrm{mg} / \mathrm{kg}$ URB597 almost completely blocked the accumulation of radioactivity in the brain, and the calculated $\mathrm{k}_{3}$ was close to zero. Thus, the $\mathrm{ED}_{50}$ value for URB597 was estimated to be $66.4 \mu \mathrm{g} / \mathrm{kg}$ in rat brain (Fig. $6 \mathrm{~B}$ ).

\section{Discussion}

In our study, $\left[{ }^{11} \mathrm{C}\right] \mathrm{DFMC}$, the most recently developed PET tracer for FAAH imaging, was used for the index measurement reflecting FAAH concentrations in the brain. The first quantitative PET study for FAAH was performed using $\left[{ }^{11} \mathrm{C}\right]$ CURB, a primary PET tracer for FAAH. In that report, the rate constant $\mathrm{k}_{3}$ for $\left[{ }^{11} \mathrm{C}\right] \mathrm{CURB}$ in PET with $2 \mathrm{TCMi}$ analysis was under 0.06 minutes $^{-1}$ in the human brain (Rusjan et al., 2013). 6-Hydroxy-[1,1'-biphenyl]-3-yl cyclohexylcarbamate is a URB597 derivative and has lower affinity $\left(\mathrm{IC}_{50}=30 \mathrm{nM}\right)$ for FAAH than URB597 $\left(\mathrm{IC}_{50}=7.7 \mathrm{nM}\right)$ (Clapper et al., 2009). $N$-(3,4-Dimethylisoxazol-5-yl)-4-(4-(2-fluoro-4-methylphenyl) thiazol-2-yl)piperazine-1-carboxamide has been recently developed as an inhibitor possessing a 3-fold higher affinity for FAAH than URB597 (Shimoda et al., 2016). Although the study subjects were different in this study, FAAH between the human and the rat is known to have high biologic homology and similar $\mathrm{V}_{\max }$ values in brains (Desarnaud et al., 1995; Giang and Cravatt, 1997; Maccarrone et al., 1998). Therefore, an estimated $\mathrm{k}_{3}$ with over 0.1 minutes $^{-1}$ in every FAAH-rich region of rat brain in the compartmental analysis of $\left[{ }^{11} \mathrm{C}\right] \mathrm{DFMC}$ (Table 1 ) would reflect a high affinity for FAAH, as described in eq. 3. Thus, $\left[{ }^{11} \mathrm{C}\right] \mathrm{DFMC}$ showing a much $\mathrm{k}_{3}$ value would be a reasonable radiotracer for PET assessments.

To promote applications using PET with $\left[{ }^{11} \mathrm{C}\right] \mathrm{DFMC}$, we tried to noninvasively estimate the macroparameter $\mathrm{K}_{\mathrm{i}}$ value, including $\mathrm{k}_{3}$, using the reference tissue method. Prior to kinetic analysis, a blocking PET study using URB597 (3 mg/kg) was conducted to determine the reference region. The heterogeneous uptake of radioactivity in all brain regions of control subjects showed significant displaceability by pretreatment with URB597, whereas radioactive uptake in the spinal cord exhibited nondisplaceable uptake (Fig. 5). In a pathologic report, FAAH-containing neurons were detected in the cerebral cortex, hippocampus, and Purkinje cells of the cerebellar cortex but not in the spinal cord (Tsou et al., 1998). However, to our knowledge, there are no reports regarding quantitative $\mathrm{PET}$ analysis using the spinal cord as a reference region. Therefore, we performed a test-retest PET study to validate the use of the spinal cord as a reference region. The ICC of the $\mathrm{K}^{\mathrm{REF}}$ value in FAAH-rich regions was 0.681-0.836 (Table 2), which supported relatively high reliability for $\mathrm{K}^{\mathrm{REF}}$ values in the PET study using $\left[{ }^{11} \mathrm{C}\right] \mathrm{DFMC}$ with PGA $_{\text {REF }}$. Meanwhile, a high variability $(>40 \%)$ was detected in the low-FAAH regions $\left(\mathrm{K}^{\mathrm{REF}}<0.005\right.$ minutes $\left.^{-1}\right)$, such as the hypothalamus and pons. The $\mathrm{K}^{\mathrm{REF}}$ value was concisely estimated with high reproducibility in FAAH-rich regions.

Another concern is the differences in distribution volumes $\left(\mathrm{K}_{1} / \mathrm{k}_{2}\right)$ between the region of interest and the reference region. Theoretically, the $\mathrm{K}^{\mathrm{REF}}$ value equals $\mathrm{k}_{2} \mathrm{k}_{3} /\left(\mathrm{k}_{2}+\mathrm{k}_{3}\right)$ in the case of $\mathrm{K}_{1} / \mathrm{k}_{2}=\mathrm{K}_{1}^{\prime} / \mathrm{k}_{2}{ }^{\prime}$ (see eq. 5). However, in this study, the distribution
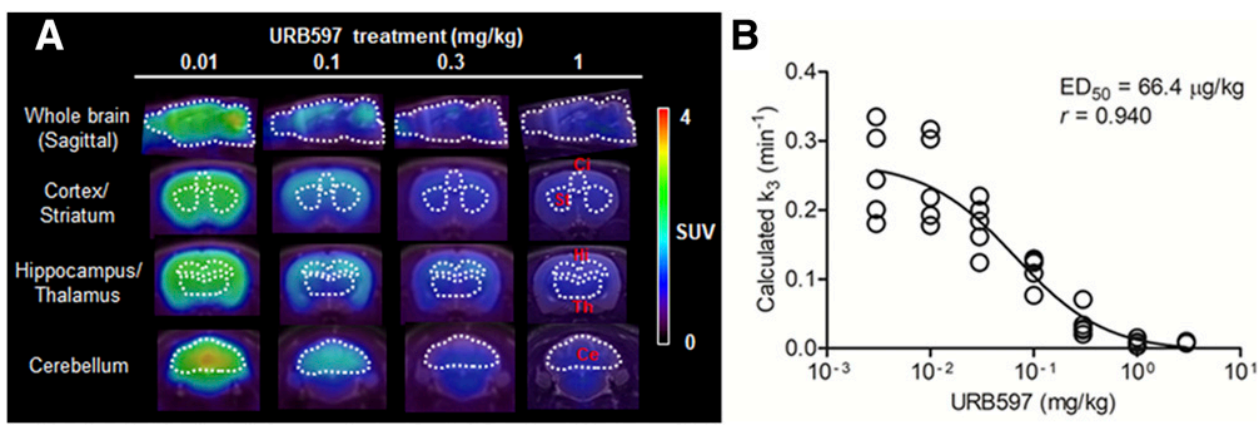

Fig. 6. Dose-response assay using URB597. (A) Representative PET/MRI images of $\left[{ }^{11} \mathrm{C}\right]$ DFMC in the brains of rats treated with different doses $(0.01,0.1,0.3$, and $1 \mathrm{mg} / \mathrm{kg})$ of URB597. (B) The relationship between calculated $\mathrm{k}_{3}$ values (minute ${ }^{-1}$ ) and doses of URB597 in various brain regions. Averaged values of calculated $k_{3}$ in the cingulate cortex, striatum, hippocampus, thalamus, and cerebellum are plotted against the dose of URB597. Ce, cerebellum; $\mathrm{Ci}$, cingulate cortex; Hi, hippocampus; St, striatum; Th, thalamus. 
volume in the spinal cord $\left(\mathrm{K}_{1}{ }^{\prime} / \mathrm{k}_{2}{ }^{\prime}\right)$ did not equal $\mathrm{K}_{1} / \mathrm{k}_{2}$ in other brain regions (see in Supplemental Table 2). Therefore, the $\mathrm{K}^{\mathrm{REF}}$ values are modified to $K_{1} k_{3} /\left(k_{2}+k_{3}\right)\left(k_{2}{ }^{\prime} / K_{1}{ }^{\prime}\right)$. In the results of the PGA $_{\mathrm{REF}}$ analysis, the $\mathrm{K}^{\mathrm{REF}}$ values in brain regions were estimated with a range of 0.004-0.011 minutes ${ }^{-1}$. Compared with the $\mathrm{K}_{\mathrm{i}}^{2 \mathrm{TCMi}}$ values, the $\mathrm{K}^{\mathrm{REF}}$ values showed high correlation ( $r>0.95$; Fig. 5C). In this regression, the slope showed $0.075\left(=\mathrm{k}_{2}{ }^{\prime} / \mathrm{K}_{1}{ }^{\prime}\right)$, which is defined as constant $\mathrm{A}$ in eq. 8 . However, a small negative bias $(-0.004)$ of the $\mathrm{K}^{\mathrm{REF}}$ value was recognized, although $\mathrm{PGA}_{\mathrm{REF}}$ and $\mathrm{K}_{\mathrm{i}}^{2 \mathrm{TCMi}}$ are proportional in theory. This small negative bias may be caused by the slight accumulation of the radiotracer at nondisplaceable sites in the spinal cord, which would cause an undesirable increase in the value of TAC in the spinal cord. Nevertheless, the spinal cord would be an adequate reference region for the estimation of regional $\mathrm{K}^{\mathrm{REF}}$ values in the present $\mathrm{PGA}_{\mathrm{REF}}$ analysis. Moreover, estimated $\mathrm{K}^{\mathrm{REF}}$ values would be a reasonable index for alternative net uptake values of $\left[{ }^{11} \mathrm{C}\right] \mathrm{DFMC}$ with $\mathrm{FAAH}$ despite including a small bias.

Finally, to propose a pharmacological application of $\left[{ }^{11} \mathrm{C}\right]$ DFMC-PET using $\mathrm{K}^{\mathrm{REF}}$ values, we estimated $\mathrm{ED}_{50}$ values of URB597 in the brain in vivo. URB597 has been developed a decade before (Fegley et al., 2005), and widely tested as a treatment of neuroinflammation and pain (Murphy et al., 2012; Lomazzo et al., 2015). Here, since the $\mathrm{K}^{\mathrm{REF}}$ value is not proportional to the regional FAAH concentrations in theory (eqs. 3 and 6), we tentatively estimated the $\mathrm{k}_{3}$ value (defined as calculated $\mathrm{k}_{3}$ ) from $\mathrm{K}^{\mathrm{REF}}$ value (eq. 9). In a comparison of the directly estimated $\mathrm{k}_{3}$ obtained by the compartmental analysis with blood sampling, the calculated $\mathrm{k}_{3}$ showed high correlation $(r=0.946)$, although a slight overestimation was exhibited (Fig. 5D). This result suggested that the calculated $\mathrm{k}_{3}$ would be favorably used as an alternative parameter of the directly estimated $\mathrm{k}_{3}$ value, which motivated us to progress our pharmacological application study. However, there is a considerable limitation in the use of calculated $\mathrm{k}_{3}$. Since the equation for calculated $\mathrm{k}_{3}$ includes two variable parameters, $\mathrm{K}_{1}$ and $\mathrm{k}_{2}$, it is important that administration of URB597 does not affect blood flow. Fortunately, administration of under $1 \mathrm{mg} / \mathrm{kg}$ (the maximum dose used in this assessment) of URB597 did not produce any effects on the initial uptake of radioactivity (Supplemental Fig. 1). Therefore, the present dose-response assay using the calculated $\mathrm{k}_{3}$ would be expected to give reasonable $\mathrm{ED}_{50}$ values of URB597 in brain regions without effects on blood flow.

Although the assay used a calculated- $\mathrm{k}_{3}$, the $\mathrm{ED}_{50}$ values of URB597 were estimated to be $66.4 \mu \mathrm{g} / \mathrm{kg}(0.2 \mu \mathrm{mol} / \mathrm{kg} \approx$ $60 \mathrm{nmol} / \mathrm{head}$ ) in the rat brain (Fig. 6B). Previously, we reported that the in vitro $\mathrm{IC}_{50}$ value of URB597 using a membrane fraction of rat brain was $19.6 \pm 3.5 \mathrm{nM}$ (Shimoda et al., 2016). It was previously reported that an ${ }^{11} \mathrm{C}$-labeled URB597 analog remained at 0.6 percentage of injection dose per gram tissue $(\% \mathrm{ID} / \mathrm{g})$ in the brain of mice 60 minutes after injection (Wyffels et al., 2010). In general, the $\% \mathrm{ID} / \mathrm{g}$ value of rat brain is roughly 10 -fold lower than that of the mouse brain because of the differences in body weights. Therefore, the present $\mathrm{ED}_{50}$ value of URB597 was supposed to be approximately $36 \mathrm{pmol} / \mathrm{g}$ brain ([injection dose of URB597 (60 nmol/head)] $\times 0.06 \% \mathrm{ID} / \mathrm{g}$ brain $)$ in PET with $\left[{ }^{11} \mathrm{C}\right] \mathrm{DFMC}$. The present in vivo $\mathrm{ED}_{50}$ value (36 nmol/kg brain) could be concisely estimated since it was close to the in vitro measurement $(19.6 \mathrm{nmol} / \mathrm{l})$.
In summary, we demonstrated the noninvasive estimation of the $\mathrm{K}^{\mathrm{REF}}$ value of $\left[{ }^{11} \mathrm{C}\right] \mathrm{DFMC}$ in FAAH-containing brain regions using the reference tissue model. Moreover, by using $K^{\mathrm{REF}}$ value, we proposed calculated $\mathrm{k}_{3}$ as an alternative index for the quantification of FAAH. Finally, using calculated $\mathrm{k}_{3}$, we estimated $\mathrm{ED}_{50}$ value of URB597 responsible for $\mathrm{FAAH}$ inhibition in rat brain as one of the pharmacological applications in vivo. Thus, our technique using PET with $\left[{ }^{11} \mathrm{C}\right] \mathrm{DFMC}$ could contribute to occupancy studies using rats for new pharmaceuticals for the treatment of central nervous system disorders targeting FAAH.

\section{Acknowledgments}

We thank the staff of the National Institute of Radiological Sciences for their support with the following: cyclotron operation, radioisotope production, radiosynthesis, and animal experiments. We thank Trent Rogers from Edanz Group (www.edanzediting.com/ac) for editing a draft of this manuscript.

\section{Authorship Contributions}

Participated in research design: Yamasaki T, Ohya T.

Conducted experiments: Yamasaki T, Zhang Y, Wakizaka H.

Contributed new reagents or analytic tools: Mori W, Nengaki N, Fujinaga M.

Performed data analysis: Yamasaki T.

Wrote or contributed to the writing of the manuscript: Yamasaki T, Ohya T, Kikuchi T, Zhang MR.

\section{References}

Ahn K, McKinney MK, and Cravatt BF (2008) Enzymatic pathways that regulate endocannabinoid signaling in the nervous system. Chem Rev 108:1687-1707.

Akaike H (1974) A new look at the statistical model identification. IEEE Trans Auto Cont 19:716-723.

Bayewitch M, Avidor-Reiss T, Levy R, Barg J, Mechoulam R, and Vogel Z (1995) The peripheral cannabinoid receptor: adenylate cyclase inhibition and $\mathrm{G}$ protein coupling. FEBS Lett 375:143-147.

Carter SF, Schöll M, Almkvist O, Wall A, Engler H, Långström B, and Nordberg A (2012) Evidence for astrocytosis in prodromal Alzheimer disease provided by 11Cdeuterium-L-deprenyl: a multitracer PET paradigm combining 11C-Pittsburgh compound B and 18F-FDG. J Nucl Med 53:37-46.

Clapper JR, Vacondio F, King AR, Duranti A, Tontini A, Silva C, Sanchini S, Tarzia G, Mor M, and Piomelli D (2009) A second generation of carbamatebased fatty acid amide hydrolase inhibitors with improved activity in vivo. ChemMedChem 4:1505-1513.

Desarnaud F, Cadas H, and Piomelli D (1995) Anandamide amidohydrolase activity in rat brain microsomes. Identification and partial characterization. J Biol Chem 270:6030-6035.

Devane WA, Hanus L, Breuer A, Pertwee RG, Stevenson LA, Griffin G, Gibson D, Mandelbaum A, Etinger A, and Mechoulam R (1992) Isolation and structure of a brain constituent that binds to the cannabinoid receptor. Science 258: 1946-1949.

Egerton A, Demjaha A, McGuire P, Mehta MA, and Howes OD (2010) The test-retest reliability of 18F-DOPA PET in assessing striatal and extrastriatal presynaptic dopaminergic function. Neuroimage 50:524-531.

Elmenhorst D, Aliaga A, Bauer A, and Rosa-Neto P (2012) Test-retest stability of

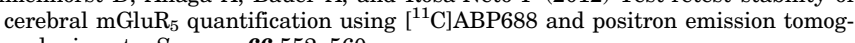
raphy in rats. Synapse 66:552-560.

Fegley D, Gaetani S, Duranti A, Tontini A, Mor M, Tarzia G, and Piomelli D (2005) Characterization of the fatty acid amide hydrolase inhibitor cyclohexyl carbamic acid 3'-carbamoyl-biphenyl-3-yl ester (URB597): effects on anandamide and oleoylethanolamide deactivation. J Pharmacol Exp Ther 313: $352-358$.

Frick A, Ahs F, Linnman C, Jonasson M, Appel L, Lubberink M, Långström B Fredrikson M, and Furmark T (2015) Increased neurokinin-1 receptor availability in the amygdala in social anxiety disorder: a positron emission tomography study with [11C]GR205171. Transl Psychiatry 5:e597.

Giang DK and Cravatt BF (1997) Molecular characterization of human and mouse fatty acid amide hydrolases. Proc Natl Acad Sci USA 94:2238-2242.

Handbook MS (1995) Rev., 7EEF. p 467, MicroMath, Inc., Salt Lake City, UT.

Innis RB, Cunningham VJ, Delforge J, Fujita M, Gjedde A, Gunn RN, Holden J, Houle S, Huang SC, Ichise M, et al. (2007) Consensus nomenclature for in vivo imaging of reversibly binding radioligands. J Cereb Blood Flow Metab 27: 1533-1539.

Kathuria S, Gaetani S, Fegley D, Valiño F, Duranti A, Tontini A, Mor M, Tarzia G, La Rana G, Calignano A, et al. (2003) Modulation of anxiety through blockade of anandamide hydrolysis. Nat Med 9:76-81.

Kumata K, Yui J, Hatori A, Maeda J, Xie L, Ogawa M, Yamasaki T, Nagai Y, Shimoda Y, Fujinaga M, et al. (2015) Development of [(11)C]MFTC for PET imaging of 
fatty acid amide hydrolase in rat and monkey brains. ACS Chem Neurosci 6: $339-346$

Lederer CM, Hollander JM, and Perlman I (1967) Table of Isotopes, 6th ed. Wiley, New York.

Li GL, Winter H, Arends R, Jay GW, Le V, Young T, and Huggins JP (2012) Assessment of the pharmacology and tolerability of PF-04457845, an irreversible inhibitor of fatty acid amide hydrolase-1, in healthy subjects. Br J Clin Pharmaco 73:706-716.

Liu P, Hamill TG, Chioda M, Chobanian H, Fung S, Guo Y, Chang L, Bakshi R, Hong Q, Dellureficio J, et al. (2013) Discovery of MK-3168: a PET tracer for imaging brain fatty acid amide hydrolase. ACS Med Chem Lett 4:509-513.

Lomazzo E, Bindila L, Remmers F, Lerner R, Schwitter C, Hoheisel U, and Lutz B (2015) Therapeutic potential of inhibitors of endocannabinoid degradation for the treatment of stress-related hyperalgesia in an animal model of chronic pain. Neuropsychopharmacology 40:488-501.

Maccarrone M, van der Stelt M, Rossi A, Veldink GA, Vliegenthart JF, and Agrò AF (1998) Anandamide hydrolysis by human cells in culture and brain. J Biol Chem 273:32332-32339.

Malek N, Popiolek-Barczyk K, Mika J, Przewlocka B, and Starowicz K (2015) Anandamide, acting via CB2 receptors, alleviates LPS-induced neuroinflammation in rat primary microglial cultures. Neural Plast 2015:130639.

Murphy N, Cowley TR, Blau CW, Dempsey CN, Noonan J, Gowran A, Tanveer R, Olango WM, Finn DP, Campbell VA, et al. (2012) The fatty acid amide hydrolase inhibitor URB597 exerts anti-inflammatory effects in hippocampus of aged rats and restores an age-related deficit in long-term potentiation. J Neuroinflammation 9:79.

Pacher P, Bátkai S, and Kunos G (2006) The endocannabinoid system as an emerging target of pharmacotherapy. Pharmacol Rev 58:389-462.

Patlak CS and Blasberg RG (1985) Graphical evaluation of blood-to-brain transfer constants from multiple-time uptake data. Generalizations. J Cereb Blood Flow Metab 5:584-590.

Patlak CS, Blasberg RG, and Fenstermacher JD (1983) Graphical evaluation of blood-to-brain transfer constants from multiple-time uptake data. $J$ Cereb Blood Flow Metab 3:1-7.

Piomelli D (2003) The molecular logic of endocannabinoid signalling. Nat Rev Neurosci 4:873-884.

Raboune S, Stuart JM, Leishman E, Takacs SM, Rhodes B, Basnet A, Jameyfield E, McHugh D, Widlanski T, and Bradshaw HB (2014) Novel endogenous N-acyl amides activate TRPV1-4 receptors, BV-2 microglia, and are regulated in brain in an acute model of inflammation. Front Cell Neurosci 8:195.

Rotstein BH, Wey HY, Shoup TM, Wilson AA, Liang SH, Hooker JM, and Vasdev N (2014) PET imaging of fatty acid amide hydrolase with [(18)F]DOPP in nonhuman primates. Mol Pharm 11:3832-3838.

Rusjan PM, Wilson AA, Mizrahi R, Boileau I, Chavez SE, Lobaugh NJ, Kish SJ, Houle S, and Tong J (2013) Mapping human brain fatty acid amide hydrolase activity with PET. J Cereb Blood Flow Metab 33:407-414.

Saijo T, Maeda J, Okauchi T, Maeda J, Morio Y, Kuwahara Y, Suzuki M, Goto N, Suzuki K, Higuchi M, et al. (2009) Utility of small-animal positron emission tomographic imaging of rats for preclinical development of drugs acting on the serotonin transporter. Int $J$ Neuropsychopharmacol 12:1021-1032.

Schlosburg JE, Kinsey SG, and Lichtman AH (2009) Targeting fatty acid amide hydrolase (FAAH) to treat pain and inflammation. AAPS $J$ 11:39-44.

Seierstad M and Breitenbucher JG (2008) Discovery and development of fatty acid amide hydrolase (FAAH) inhibitors. $J$ Med Chem 51:7327-7343.

Shimoda Y, Fujinaga M, Hatori A, Yui J, Zhang Y, Nengaki N, Kurihara Y, Yamasaki T, Xie L, Kumata K, et al. (2016) N-(3,4-Dimethylisoxazol-5-yl)piperazine-4-[4-(2-fluoro-4-[(11)C] methylphenyl)thiazol-2-yl]-1-carboxamide: a promising positron emission tomography ligand for fatty acid amide hydrolase. Bioorg Med Chem 24:627-634.

Shimoda Y, Yui J, Zhang Y, Hatori A, Ogawa M, Fujinaga M, Yamasaki T, Xie L, Kumata K, and Zhang MR (2015) Radiosynthesis and evaluation of N-(3,4 dimethylisoxazol-5-yl)piperazine-4-[4-(4-fluorophenyl) thiazol-2-yl]-1-[C-11] carboxamide for in vivo positron emission tomography imaging of fatty acid amide hydrolase in brain. RSC Adv 5:106122-106127.

Takei M, Kida T, and Suzuki K (2001) Sensitive measurement of positron emitters eluted from HPLC. Appl Radiat Isot 55:229-234.

Thomas EA, Cravatt BF, Danielson PE, Gilula NB, and Sutcliffe JG (1997) Fatty acid amide hydrolase, the degradative enzyme for anandamide and oleamide, has selective distribution in neurons within the rat central nervous system. $J$ Neurosci Res 50:1047-1052.

Tsou K, Nogueron MI, Muthian S, Sañudo-Pena MC, Hillard CJ, Deutsch DG, and Walker JM (1998) Fatty acid amide hydrolase is located preferentially in large neurons in the rat central nervous system as revealed by immunohistochemistry. Neurosci Lett 254:137-140.

Wang L, Yui J, Wang Q, Zhang Y, Mori W, Shimoda Y, Fujinaga M, Kumata K, Yamasaki T, Hatori A, et al. (2016) Synthesis and preliminary PET imaging studies of a FAAH radiotracer ([11C]MPPO) based on $\alpha$-ketoheterocyclic scaffold. ACS Chem Neurosci 7:109-118.

Wilson AA, Garcia A, Parkes J, Houle S, Tong J, and Vasdev N (2011) [11C]CURB: evaluation of a novel radiotracer for imaging fatty acid amide hydrolase by positron emission tomography. Nucl Med Biol 38:247-253.

Wyffels L, Muccioli GG, Kapanda CN, Labar G, De Bruyne S, De Vos F, and Lambert DM (2010) PET imaging of fatty acid amide hydrolase in the brain: synthesis and biological evaluation of an 11C-labelled URB597 analogue. Nucl Med Biol 37: $665-675$.

Yamasaki T, Fujinaga M, Yui J, Ikoma Y, Hatori A, Xie L, Wakizaka H, Kumata K, Nengaki N, Kawamura K, et al. (2014) Noninvasive quantification of metabotropic glutamate receptor type 1 with $\left[{ }^{11}\right.$ C]ITDM: a small-animal PET study. $J$ Cereb Blood Flow Metab 34:606-612.

Address correspondence to: Dr. Tomoteru Yamasaki, Department of Advanced Nuclear Medicine Sciences, National Institute of Radiological Sciences, Quantum Medical Science Directorate, National Institutes for Quantum and Radiological Science and Technology, 4-9-1 Anagawa, Inage-ku, Chiba 263-8555, Japan. E-mail: yamasaki.tomoteru@qst.go.jp 